\title{
END USER COMPUTING SATISFACTION: MODEL ANALISIS KEPUASAN PENGGUNA APLIKASI MENGGUNAKAN PARTIAL LEAST SQUARE STRUCTURAL EQUATION MODELING (STUDI KASUS)
}

\author{
Aditia Angga Perdana ${ }^{1}$, Meinarini Catur Utami ${ }^{2}$, Qurrotul Aini ${ }^{* 3}$ \\ 1,2,3 Universitas Islam Negeri Syarif Hidayatullah, Jakarta \\ Email: ${ }^{1}$ aditia.anggaperdana@mhs.uinjkt.ac.id, ${ }^{2}$ meinarini@uinjkt.ac.id, \\ ${ }^{3}$ qurrotul.aini@uinjkt.ac.id \\ "Penulis Korespondensi
}

(Naskah masuk: 25 Mei 2020, diterima untuk diterbitkan: 17 November 2021)

\begin{abstract}
Abstrak
Toyota Sales Operation atau dikenal sebagai AUTO2000 adalah bagian dari perseroan terbuka PT. Astra yang beroperasi di sektor otomotif dan sudah menjalankan beberapa servis untuk menaikkan kepuasan pelanggan. Salah satunya dengan menghadirkan AUTO2000 Mobile, sebagai fasilitas pemesanan servis kendaraan secara online yang bertujuan untuk memudahkan pengguna untuk mempercepat proses bisnis dan mengurangi bahkan menghilangkan durasi waktu mengantri. Namun dalam penerapannya masih banyak kekurangan maupun kelemahan yang dirasakan pengguna di antaranya masih ada bugs, tidak ada fitur real-time chat serta beberapa pengguna masih kesulitan menggunakan aplikasi tersebut. Capaian riset ini adalah menginvestigasi tingkat kepuasan pelanggan dan memperoleh variabel signifikan yang berdampak pada kepuasan pelanggan Aplikasi AUTO2000 Mobile. Metode riset ini menerapkan End-User Computing Satisfaction (EUCS) dengan cara kuantitatif dan diseminasi kuesioner mendapatkan informasi dari objek penelitian. Populasi dalam riset ini adalah pemakai AUTO2000 Mobile. Dari populasi tersebut terpilih sebanyak 252 responden dan diseminasi kuesioner dilaksanakan melalui daring dan membagikan secara langsung dengan cara simple random sampling. Setelah itu, data yang dikumpulkan diolah dengan program Microsoft Excel 2016 serta PLS-SEM mengoperasikan tool SmartPLS 3.2.7. Hasilnya, terdapat 5 jalur yang diuji, $\mathrm{H}_{0}$ ditolak untuk empat variabel dan $\mathrm{H}_{0}$ diterima untuk satu variabel. Terdapat empat variabel yang berpengaruh signifikan pada kepuasan pelanggan AUTO2000 Mobile yaitu: accuracy, content, format dan ease of use.
\end{abstract}

Kata kunci: kepuasan pelanggan, AUTO2000 mobile, End-User Computing Satisfaction (EUCS), PLS-SEM, SmartPLS

\section{ANALYSIS OF AUTO2000 MOBILE USER SATISFACTION USING END USER COMPUTING SATISFACTION MODEL}

\begin{abstract}
Toyota Sales Operation or known as AUTO2000 is part of the public company PT. Astra that engaged in the automotive sector and has done several service improvements to increase customer satisfaction. One of them is by presenting AUTO2000 Mobile, which is an online vehicle service ordering facility that is implemented to make it easier for users, therefore it is considered to speed up business processes and reduce or even eliminate the duration of the queue. But in its implementation there are still many shortcomings and weaknesses felt by users including bugs, there is no real-time chat feature, and some users still have difficulty using the application, hence it is prominent to conduct study dealing with end-user satisfaction. The aim of this research is to analysis of end-user satisfaction level and determine the variables that impact end-user satisfaction of the AUTO2000 Mobile Application. This research method deals with End-User Computing Satisfaction (EUCS) with a quantitative approach and questionnaire distribution to obtain data from respondents. The research subject in this study are AUTO2000 Mobile users. The population consist of 252 respondents and questionnaires are distributed online and offline with simple random sampling. Furthermore, the obtained data were analyzed using Ms. Excel 2016 and with the PLS-SEM approach using SmartPLS 3.2.7. The result, from the 5 paths tested, $H_{0}$ is rejected for four variables and $H_{0}$ is accepted for one variable. There are four variables that have a significant effect on customer satisfaction of AUTO2000 Mobile, namely: accuracy, content, format and ease of use.
\end{abstract}

Keywords: customer satisfaction, AUTO2000 mobile, End-User Computing Satisfaction (EUCS), PLS-SEM, SmartPLS 


\section{PENDAHULUAN}

PT Astra Internasional Tbk dalam memajukan sektor teknologi informasi, salah satunya membentuk AUTO2000 Mobile pada tahun 2010 yang hadir dalam versi Android serta iOS. Adanya AUTO2000 Mobile tentunya akan memudahkan customer dalam booking service kendaraan dari yang harus datang ke dealer maupun layanan home service. Selain itu juga ada katalog kendaraan roda empat yang siap memberikan informasi secara detail ke pelanggan serta masih banyak fitur lainnya. Masyarakat dapat menikmati layanan secara penuh di aplikasi tersebut dengan hanya login di aplikasi tersebut. Sejak April 2019 AUTO2000 Mobile telah memiliki jumlah unduhan dengan total lebih dari 8.000 user di Google Playstore maupun App Store untuk wilayah seluruh Indonesia. Untuk persebaran lima kota teratas unduhan AUTO2000 Mobile mempunyai total unduhan 5.585. Dan berikut ini persebaran 10 kota teratas unduhan AUTO2000 Mobile di Indonesia pada Gambar 1. Dari wilayah Jakarta, mengacu pada Tabel 1.1 Jakarta Selatan memiliki jumlah outlet Vehicle, Service, Part (VSP) terbanyak dibanding di wilayah lainnya, yaitu sebanyak 7 outlet. Pertumbuhan unduh dan pasang aplikasi AUTO2000 Mobile melalui Google Playstore dan App Store dari Maret 2018 sampai April 2019 sebesar 6,04\%.

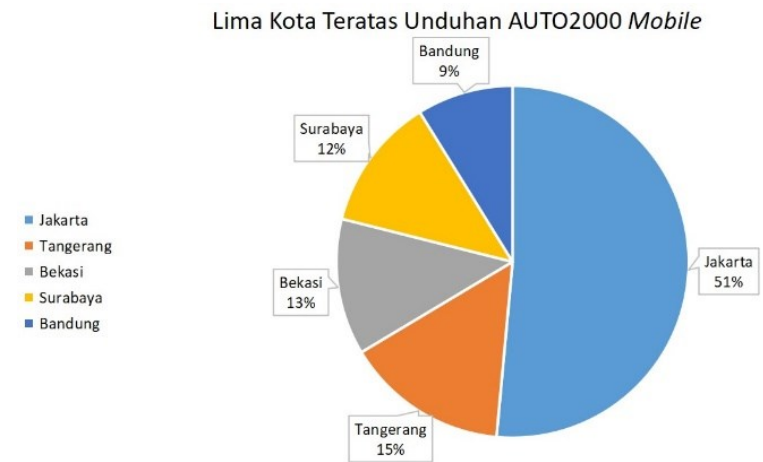

Gambar 1. Unduhan AUTO2000 Mobile April 2019

Tabel 1. Outlet Vehicle Service Part (VSP) Wilayah Jakarta

\begin{tabular}{cc} 
& Wilayah Jakarta \\
\hline Wilayah & $\begin{array}{c}\text { Jumlah Outlet Vehicle } \\
\text { Service Part (VSP) }\end{array}$ \\
\hline Jakarta Barat & 5 \\
Jakarta Pusat & 4 \\
Jakarta Selatan & 7 \\
Jakarta Timur & 2 \\
Jakarta Utara & 3 \\
\hline
\end{tabular}

Pada AUTO2000 Mobile ternyata masih ada kekurangan, berdasarkan hasil observasi serta wawancara ke perwakilan AUTO2000 Head Office, AUTO2000 Cilandak, AUTO2000 Body Paint Ciledug, AUTO2000 Radio Dalam dan pengguna AUTO2000 Mobile, peneliti menemukan beberapa fakta, yaitu: (1) sering terjadinya error atau bugs (masalah) ketika menggunakan aplikasi AUTO2000 Mobile; (2) beberapa pengguna masih kesulitan dalam menggunakan aplikasi AUTO2000 Mobile; (3) tidak ada fitur real-time chat pada AUTO2000 Mobile; (4) tidak ada fitur pembatalan dalam booking layanan sehingga pengguna yang ingin membatalkan pesanan harus melalui telepon, SMS, Whatsapp dan Email.

Berdasarkan pengamatan dan wawancara terhadap pihak terkait, penulis mendapatkan informasi bahwa hingga saat ini aplikasi AUTO2000 Mobile tidak sekalipun dianalisis variabel atau kriteria yang berdampak pada kepuasan pelanggan aplikasi. Dengan mempunyai visi yang telah disampaikan sebelumnya, sangat jelas yaitu mengutamakan pengguna aplikasi AUTO2000 Mobile adalah salah satu cara untuk memiliki proses bisnis kelas dunia. Ini berarti kepuasan pengguna juga turut andil dalam menentukan proses bisnis AUTO2000 ke depannya.

Sasaran akhir dari penelitian ini adalah memperoleh variabel atau kriteria berpengaruh pada kepuasan pelanggan terhadap Aplikasi AUTO2000 Mobile menggunakan model EUCS.

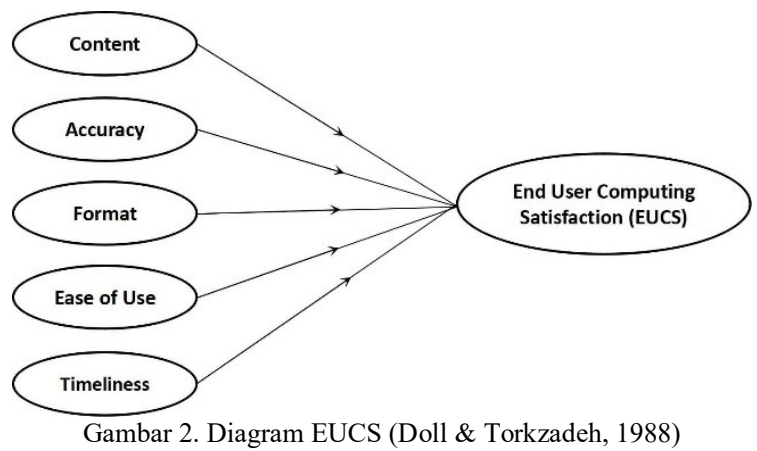

Studi ini mengimplementasikan metode kuantitatif dengan mengadopsi model End-User Computing Satisfaction (EUCS) yang diperlihatkan pada Gambar 2. Model EUCS terdiri atas 5 variabel pengukuran aspek teknologi meliputi konten (content), akurasi (accuracy), format, kemudahan penggunaan (ease of use), dan ketepatan waktu (timeliness) (Doll \& Torkzadeh, 1988). Model ini dipilih karena dalam perhitungan derajat kualitas sebuah sistem atau aplikasi yang sedang beroperasi, maka lembaga harus memahami bagaimana mengurangi keluhan pelanggan dan memperbaiki fasilitas atau fitur meningkatkan kepuasan pelanggan dapat diperbaiki berupa feedback sebagai upaya untuk memperbaiki sistem atau aplikasi tersebut (McLeod Jr \& Schell, 2008). Hipotesis penelitian diadopsi berdasarkan teori EUCS. Oleh karena itu, hipotesis dalam penelitian ini dinyatakan sebagai berikut:

$\mathrm{H}_{0}$ : Variabel content, accuracy, format, ease of use dan timeliness berdampak negatif terhadap EndUser Satisfaction.

$\mathrm{H}_{1}$ : Variabel content, accuracy, format, ease of use dan timeliness berdampak positif terhadap EndUser Satisfaction. 
Adapun penelitian yang relevan dengan penelitian ini diperlihatkan pada Gambar 3. Terdapat 2 hasil penelitian yang beririsan dengan penelitian penulis yaitu Jati et al. (2015) dan Hidayah \& Rustamaji (2018). Hal ini dimungkinkan karena penggunaan variabel dan tool yang sama. Penelitian ini bila dibandingkan dengan 2 hasil penelitian sebelumnya memiliki keunggulan yaitu: analisis kepuasan pelanggan terhadap aplikasi AUTO2000 Mobile saat ini merupakan objek penelitian baru khususnya di domain dengan menggunakan model EUCS dan PLS-SEM serta berkontribusi pada 4 variabel signifikan yaitu: accuracy, content, format dan ease of use yang berpengaruh pada aplikasi layanan otomotif; penentuan sampel selain menggunakan 10 time rule of thumb juga menggunakan rumus Slovin, sehingga memiliki jumlah sampel yang lebih banyak dibanding kedua penelitian tersebut, selain itu jumlah variabel yang signifikan lebih banyak dari Jati et al. (2015) namun bila dibandingkan dengan Hidayah \& Rustamaji (2018) jumlah variabel signifikan lebih sedikit. Kontribusi secara keilmuan sebagai referensi penelitian kuantitatif dengan metode EUCS di bidang kajian layanan otomotif serta kontribusi secara teknis bagi AUTO2000 adalah perbaikan layanan AUTO2000 Mobile khususnya ketepatan waktu (timeliness).

\section{METODE PENELITIAN}

Metode pengumpulan data mencakup observasi, wawancara, dan survei. Observasi bertujuan mendapatkan informasi kondisi, proses bisnis dan penggunaan AUTO2000 mobile di Kantor Pusat AUTO2000. Sedangkan wawancara dilakukan dengan Ibu Agatha Gabriele S.I.Kom di Departemen Communication \& Digital Marketing AUTO2000. Hasil utama wawancara seputar pelaksanaan dan kendala AUTO2000 Mobile di sisi customer. Survei dilakukan dengan kuesioner dalam dua tahap, yaitu: pre-test dan real questionnaire. Pre-test dilakukan secara langung berinteraksi dengan customer di kantor AUTO200 Jakarta Selatan. Kemudian, tahap real questionnaire dilakukan dengan menyebar secara langsung dan share link melalui media sosial berupa Google Form. Populasi pelanggan AUTO2000 Mobile area Jakarta Selatan berjumlah 650 orang. Studi ini menerapkan cara purposive sampling, dimana peneliti menentukan jumlah responden berdasarkan alasan khusus. Dari 650 orang tersebut, peneliti hanya menjadikan 252 pelanggan sebagai responden. Total ini diperoleh lebih besar dari batas minimum responden yaitu 248, merupakan hasil komputasi dengan menerapkan formula Slovin disertai ambang error $(e)$ sebesar 5\%. Pengolahan tersusun atas 2 yaitu olahan kependudukan dan statistik. Pertama, peneliti menjalankan pengolahan fakta kependudukan yang mengaplikasikan perangkat lunak Microsoft Excel. Fakta responden dipilah mengacu pada gender, umur, pendidikan, dan status/level pengguna AUTO2000 Mobile. Kedua, peneliti menggunakan analisis deskriptif presentase frekuensi dengan menggunakan software Microsoft Excel untuk mendeskripsikan persepsi responden atau kecenderungan jawaban responden atas item-item pertanyaan (indikator) yang diajukan dalam penelitian ini.

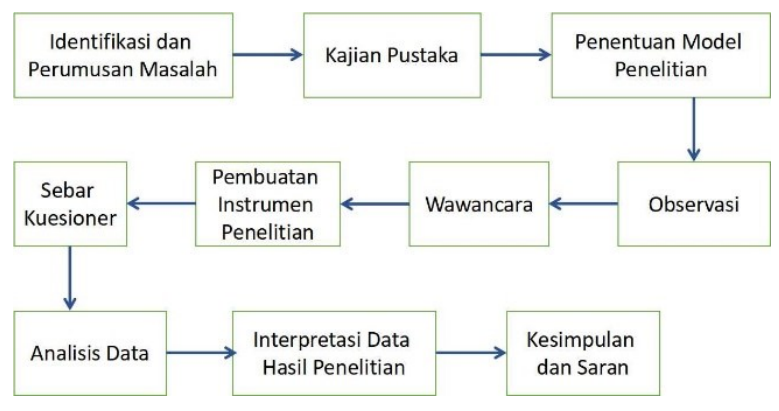

Gambar 3. Tahapan Penelitian

Adapun tahapan penelitian ini terangkum dalam Gambar 3, yang diawali dengan identifikasi dan rumusan masalah, yang didukung oleh kajian pustaka dan membuat model penelitian. Lalu, dilaksanakan observasi, wawancara, dan pembuatan instrumen penelitian. Berlanjut persebaran kuesioner ke objek riset diikuti dengan proses analisis data, interpretasi data, dan terakhir menarik kesimpulan serta saran.

\section{TINJAUAN PUSTAKA}

Penelitian ini didukung dari beberapa pustaka tentang EUCS, variabel EUCS dan PLS.

\subsection{End-User Computing Satisfaction (EUCS)}

EUCS adalah penilaian atas semua sistem informasi atau aplikasi yang dijalankan oleh pelanggan sebuah sistem/aplikasi yang terkait dengan kemahiran penggunaan aplikasi tersebut. Kemahiran pemanfaatan aplikasi tersebut dihitung untuk mendapatkan informasi apakah aplikasi yang dijalankan berdaya guna dan cocok seperti yang diharapkan (Aggelidis \& Chatzoglou, 2012).

EUCS adalah sebuah bingkai kerja yang bisa dimanfaatkan sebagai perhitungan kepuasan suatu aplikasi yang beracuan pada permahaman pemakai akhir aplikasi, yaitu: dengan tingkat proporsi antara keinginan dan fakta real aplikasi. Bingkai kerja ini berfokus pada kepuasan (satisfaction) pemakai akhir pada fitur teknologi yang dapat menganalisis isi, akurasi, format, presisi waktu, dan mudah tidaknya pemanfaatan sebuah aplikasi. Implementasi EUCS terlihat pada ranah perhitungan kepuasan web (Husain, 2018); katalog online untuk akses publik (Restanti \& Astuti, 2017); dan e-learning (Darwi \& Efrizon, 2019; Yazid et al, 2019). 


\subsection{Variabel EUCS}

\section{a) Content (CON)}

CON dalam studi ini diterapkan sebagai penilaian kepuasan pelanggan yang dikaji dari perspektif muatan sebuah aplikasi. Kriteria ini menilai apakah aplikasi menciptakan informasi yang cocok dengan keperluan pelanggan (Fitriansyah \& Harris, 2018). Kriteria CON diterapkan oleh Pratama et al. (2012). Adapun keluarannya membuktikan bahwa tiga kriteria pada model EUCS berdampak terhadap kepuasan pelanggan yaitu khususnya kriteria CON.

\section{b) Accuracy (ACC)}

Kriteria ACC dalam studi memiliki target pada penilaian kepuasan pelanggan dari perspektif kecermatan fakta ketika aplikasi mendapatkan masukan lalu dianalisis. Kecermatan aplikasi dapat dinilai Ketika frekuensi pemanfaatan aplikasi menciptakan keluaran yang tidak benar saat menganalisis masukan dari pelanggan, juga dapat ditinjau banyaknya kesalahan ketika menganalisis fakta (Setiawan, 2016). Kriteria ini dimanfaatkan Marlindawati (2014) pada risetnya, namun keluarannya mengungkapkan bahwa kriteria ini tidak berdampak signifikan pada kepuasan pelanggan.

\section{c) Format (FOR)}

Kriteria FOR berfungsi sebagai penilai kepuasan pelanggan dari perspektif antar muka sistem tersebut. Mengacu pada pernyataan Rasman (2012), FOR memiliki sasaran menilai kepuasan pelanggan dari sudut antar muka dan seni perancangan sistem atau aplikasi, FOR dari keluaran atau fakta yang diciptakan aplikasi apakah interface aplikasi eye catching dan meringankan pelanggan saat memanfaatkannya. Selain itu, Rasman (2012) juga menerapkan kriteria ini dalam risetnya, yang mana keluarannya mengungkapkan bahwa kriteria FOR mempunyai derajat kepuasan yang agak tinggi bila diproporsikan dengan kriteria lain.

\section{d) Ease of use (EOU)}

Kriteria EOU dimanfaatkan sebagai penilai kepuasan dari sudut kegampangan pelanggan atau user friendly ketika memanfaatkan aplikasi seperti mendapatkan data yang diperlukan. Kriteria ini diterapkan Setiawan (2016) dan keluarannya memperlihatkan bahwa kriteria EOU berdampak penting pada kepuasan pelanggan. e) Timeliness (TIM)

Kriteria TIM berfungsi sebagai penilai kepuasan pelanggan dari sudut kecermatan waktu aplikasi ketika menyuguhkan fakta yang diperlukan pelanggan. Kriteria ini menegaskan bahwa semua masukan yang dilaksanakan pelanggan secara cepat diolah dan disajikan serta hasil divisualisasikan secara akurat. Mengurangi tenggat proses yang lama. Keluaran studi Marlindawati (2014) mengungkapkan kalau kriteria TIM berdampak pada penerapan aplikasi.

\subsection{Partial Least Square (PLS)}

PLS awalnya diciptakan oleh Herman Wold dan diseminasikan pada publik ketika tahun 1974. PLS adalah teknik lain pada Structural Equation Modeling (SEM) yang bisa dimanfaatkan sebagai pengolahan yang dirasa baik pada tipe skala data (data nominal, data interval dan rasio) dan requirement pemahaman yang dinamis (Yamin \& Kurniawan, 2011). Sasaran pentingnya yaitu memudahkan studi untuk memperoleh kuantitas kriteria tersembunyi dalam melaksanakan prakiraan dan diterapkan juga pada pencocokan dasar teori atau uji dugaan/asumsi. Terdapat beberapa keunggulan penggunaan metode PLS, seperti: (Yamin \& Kurniawan, 2011; Urbach \& Ahlemann, 2010)

a) PLS dapat digunakan pada ukuran sampel yang kecil sesuai dengan kebutuhan dan distribusi sampel yang tidak normal.

b) PLS-SEM dapat menganalis sebuah model yang memiliki banyak jalur/link dan cenderung rumit.

c) PLS mampu mengestimasi konstruk pada model formatif dan reflektif secara konsisten.

\section{HASIL DAN PEMBAHASAN}

Di tahap ini, peneliti melakukan pengolahan kependudukan responden. Fakta kependudukan meliputi gender, umur, profesi, kondisi mobil saat dibeli dan pengeluaran total per bulan. Berikut disajikan hasil analisis demografis yang ditunjukkan pada Gambar 5- Gambar 9.

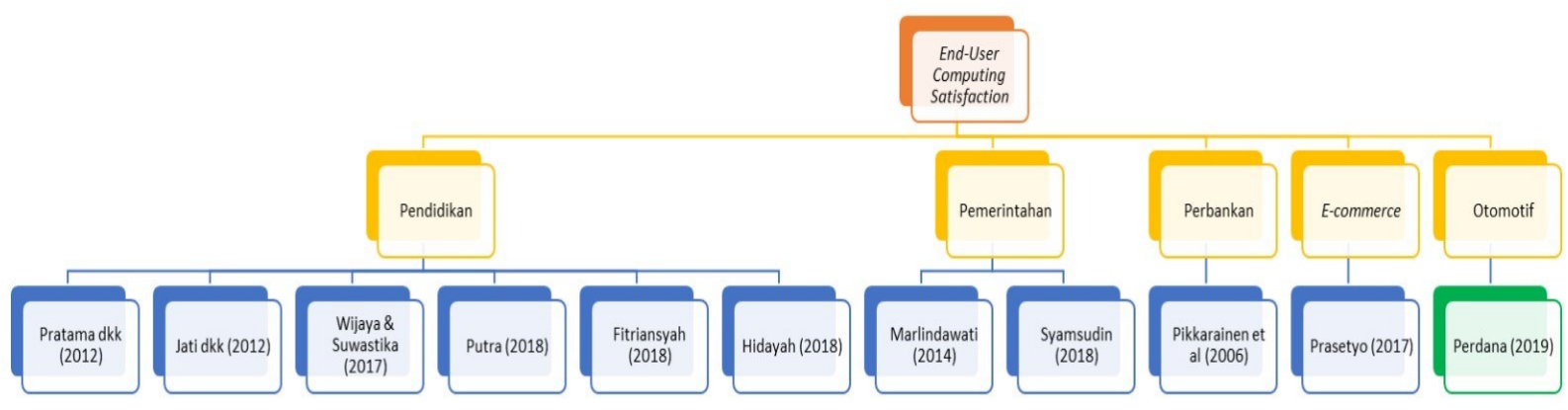

Gambar 3. Ranah Penelitian 
Jenis Kelamin

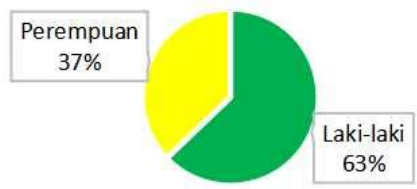

- Laki-laki $=$ Perempuan

Gambar 5. Gender Responden

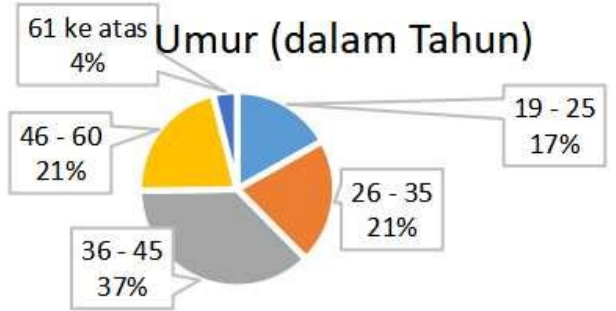

- $19-25=26-35=36-45=46-60=61 \mathrm{ke}$ atas

Gambar 6. Umur Responden

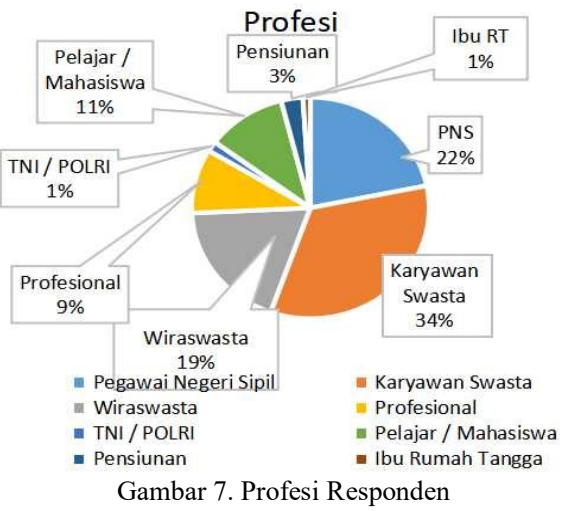

Kondisi Mobil saat Dibeli

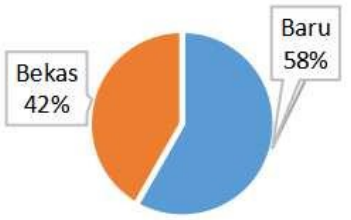

= Baru $=$ Bekas

Gambar 8. Kondisi Mobil saat Dibeli Responden
Pengeluaran Total per Bulan (Rupiah)

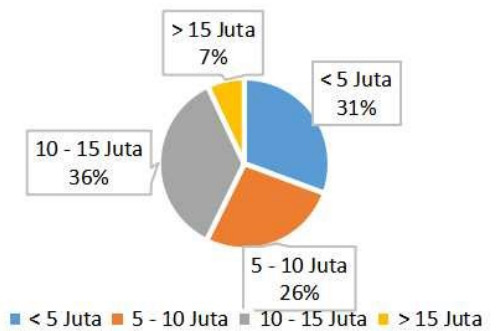

Gambar 9. Pengeluaran Total per Bulan Responden

Kemudian, menjalankan pengolahan perhitungan uji yang tersusun atas 4 langkah perhitungan, yaitu: individual item reliability, internal consistency reliability, convergent validity, dan discriminant validity. Deskripsi keluaran perhitungan dipaparkan sebagai berikut.

\subsection{Individual Item Realibility}

Faktor loading terstandar memperlihatkan derajat hubungan antar variabel dengan konstruknya dengan memperhatikan kuantitas outer loading. Kuantitas outer loading lebih besar dari 0,7 dapat dinyatakan bagus dengan maksud variabel itu valid dalam komputasi konstruknya. Berdasarkan acuan kuantitas outer loading, selanjutnya dengan perhitungan pada SmartPLS 3.2.7, bisa ditunjukkan pada Tabel 2 bahwa dari 9 item yaitu ACC1, ACC3, ACC4, CON1, CON2, CON3, CON4, EOU1 dan EOU4 yang mempunyai kuantitas outer loading lebih kecil dari 0,7, jadi 9 item tersebut dapat dihilangkan berjenjang hingga terbebas dari item yang mempunyai kuantitas outer loading lebih kecil dari 0,7 .

Tabel 2. Luaran Awal Perhitungan Faktor Loading dengan

\begin{tabular}{|c|c|c|c|c|c|c|}
\hline & \multicolumn{6}{|c|}{ SmartPLS } \\
\hline & accuracy & content & $\begin{array}{l}\text { Ease of } \\
\text { use }\end{array}$ & $\begin{array}{c}\text { End-user } \\
\text { satisfaction }\end{array}$ & format & timelineness \\
\hline ACC1 & 0,670 & & & & & \\
\hline $\mathrm{ACC} 2$ & 0,723 & & & & & \\
\hline ACC3 & 0,674 & & & & & \\
\hline ACC4 & 0,686 & & & & & \\
\hline CON1 & & 0,672 & & & & \\
\hline CON2 & & 0,554 & & & & \\
\hline CON3 & & 0,681 & & & & \\
\hline CON4 & & 0,685 & & & & \\
\hline CON5 & & 0,747 & & & & \\
\hline EOU1 & & & 0,573 & & & \\
\hline EOU2 & & & 0,743 & & & \\
\hline EOU3 & & & 0,770 & & & \\
\hline EOU4 & & & 0,675 & & & \\
\hline EUS1 & & & & 0,755 & & \\
\hline EUS2 & & & & 0,751 & & \\
\hline EUS3 & & & & 0,796 & & \\
\hline FOR1 & & & & & 0,704 & \\
\hline FOR2 & & & & & 0,720 & \\
\hline FOR3 & & & & & 0,726 & \\
\hline FOR4 & & & & & 0,730 & \\
\hline TIM1 & & & & & & 0,744 \\
\hline TIM2 & & & & & & 0,720 \\
\hline TIM3 & & & & & & 0,722 \\
\hline TIM4 & & & & & & 0,739 \\
\hline
\end{tabular}

Sesudah dijalankan perhitungan seperti penghapusan item lain bertahap, didapatkan pula item ACC3, ACC4, CON3, CON4 dan EOU4 masih dapat dimanfaatkan sebab kuantitasnya mencukupi kuantitas acuan outer loading sesudah penghilangan 
item ACC1, CON1, CON2 dan EOU1. Penghilangan 4 item menyebabkan kuantitas factor loading seluruh item sudah mencukupi kuantitas acuan faktor loading serta dapat diterapkan perhitungan berikutnya yang ditunjukkan pada Tabel 3.

Tabel 3. Luaran Perhitungan Faktor Loading setelah Penghilangan Item

\begin{tabular}{lcccccc}
\multicolumn{5}{c}{ Penghilangan Item } \\
\hline & accuracy & content & $\begin{array}{c}\text { Ease of } \\
\text { use }\end{array}$ & $\begin{array}{c}\text { End-user } \\
\text { satisfaction }\end{array}$ & format & timelineness \\
\hline ACC2 & 0,700 & & & & & \\
ACC3 & 0,750 & & & & & \\
ACC4 & 0,734 & & & & & \\
CON3 & & 0,731 & & & & \\
CON4 & & 0,790 & & & & \\
CON5 & 0,764 & 0,740 & & & \\
EOU2 & & & 0,818 & & & \\
EOU3 & & & 0,722 & 0,755 & & \\
EOU4 & & & & 0,752 & & \\
EUS1 & & & 0,795 & 0,704 & \\
EUS2 & & & & 0,720 & \\
EUS3 & & & & 0,726 & \\
FOR1 & & & & 0,730 & \\
FOR2 & & & & & 0,744 \\
FOR3 & & & & 0 & 0,720 \\
FOR4 & & & & & \\
TIM1 & & & & & \\
TIM2 & & & & & \\
TIM3 & & & & & \\
TIM4 & & & & & & \\
\hline
\end{tabular}

\subsection{Internal Consistency Reliability}

Pengolahan kuantitas ini dijalankan dengan membandingkannya pada kuantitas composite reliability (CR) lebih besar dari 0,7. Tabel 4 menunjukkan luaran komputasi secara manual dan dibandingkan dengan alat bantu SmartPLS 3.2.7, ternyata semua kuantitas CR dari seluruh kriteria sudah mencukupi requirement dan kesahihan agar bisa dimanfaatkan pada studi ini.

$\rho_{c}=\frac{\left(\sum \lambda_{i}\right)^{2} \operatorname{var} F}{\left(\sum \lambda_{i}\right)^{2} \operatorname{var} F+\sum \Theta_{i i}}$

Tabel 4. Luaran Pengujian Composite Reliability (CR)

\begin{tabular}{cc}
\hline & Composite Reliability \\
\hline Accuracy & 0,772 \\
Content & 0,806 \\
Ease of use & 0,805 \\
End-user \\
satisfaction \\
format \\
Timeliness
\end{tabular}

\subsection{Convergent Validity}

Langkah selanjutnya adalah menjalankan perhitungan convergent validity yaitu berupa kuantitas average variance extracted (AVE), AVE menunjukkan kuantitas atau varian kriteria yang terdapat pada kriteria tersembunyi. Kuantitas AVE dikatakan bagus bila mampu menghasilkan convergent validity minimum 0,5 . Adapun maksud dari 0,5 ini adalah kriteria tersembunyi setidaknya memiliki kuantitas reratanya lebih dari setengah keragaman dari indikatornya. Tabel 5 menunjukkan luaran komputasi tanpa perangkat lunak dan dibandingkan dengan bantuan SmartPLS 3.2.7. Terlihat semua kuantitas AVE dari seluruh kriteria telah mencukupi requirement dan valid agar bisa dimanfaatkan dalam studi ini.

$A V E=\frac{\left(\sum \lambda_{i}\right)^{2} \operatorname{var} F}{\left(\sum \lambda_{i}\right)^{2} \operatorname{var} F+\sum \Theta_{i i}}$

Tabel 5. Luaran Perhitungan Average Variance Extracted (AVE)

\begin{tabular}{cc}
\hline & $\begin{array}{c}\text { Average Variance } \\
\text { Extracted (AVE) }\end{array}$ \\
\hline Accuracy & 0,530 \\
Content & 0,581 \\
Ease of use & 0,579 \\
End-user & 0,589 \\
satisfaction & 0,518 \\
Format & 0,535 \\
Timeliness & \\
\hline
\end{tabular}

\subsection{Discriminant Validity}

Perhitungan ini bisa dijalankan dengan dua metode, mengkoreksi nilai cross loading dan kriteria Fornell-Larcker. Cross loading diperoleh dengan mengkorelasikan nilai outer loading sebuah indikator, misal pada Tabel 6 , ACC2 memiliki nilai cross loading 0,700 terhadap konstruknya 'accuracy' dibandingkan dengan nilai cross loading ACC2 terhadap konstruk 'content' sebesar 0,341. Hal ini membuktikan bahwa tiap indikator (ACC2, ACC3 dan seterusnya) memiliki nilai cross loading lebih tinggi dibandingkan korelasi konstruk lainnya dan dapat disimpulkan bahwa indikator ACC2 lebih baik daripada indikator di konstruk lainnya (Chin, 1998). Kedua, dengan cara menghitung nilai kroteria Fornell-Larcker, caranya adalah rasio kuantitas akar AVE, yaitu kuantitas akar AVE harus lebih besar disbanding korelasi antara konstruk dengan konstruk lainnya. Luarannya ditunjukkan Tabel 6 , terlihat kuantitas cross loading ditulis lebih tebal tiap kriteria yang lebih besar dari korelasi dengan konstruk blok lainnya.

\begin{tabular}{lcccccc}
\multicolumn{7}{c}{ Tabel 6. Luaran Perhitungan Cross Loading } \\
\hline & accuracy & content & $\begin{array}{c}\text { Ease of } \\
\text { use }\end{array}$ & $\begin{array}{c}\text { End-user } \\
\text { satisfaction }\end{array}$ & format & timelineness \\
\hline ACC2 & $\mathbf{0 , 7 0 0}$ & 0,341 & 0,386 & 0,394 & 0,372 & 0,476 \\
ACC3 & $\mathbf{0 , 7 5 0}$ & 0,419 & 0,397 & 0,399 & 0,340 & 0,427 \\
ACC4 & $\mathbf{0 , 7 3 4}$ & 0,432 & 0,396 & 0,415 & 0,389 & 0,490 \\
CON3 & 0,465 & $\mathbf{0 , 7 3 1}$ & 0,400 & 0,412 & 0,437 & 0,442 \\
CON4 & 0,385 & $\mathbf{0 , 7 9 0}$ & 0,336 & 0,447 & 0,441 & 0,410 \\
CON5 & 0,404 & $\mathbf{0 , 7 6 4}$ & 0,486 & 0,452 & 0,503 & 0,484 \\
EOU2 & 0,403 & 0,448 & $\mathbf{0 , 7 4 0}$ & 0,431 & 0,365 & 0,427 \\
EOU3 & 0,474 & 0,423 & $\mathbf{0 , 8 1 8}$ & 0,520 & 0,411 & 0,522 \\
EOU4 & 0,347 & 0,351 & $\mathbf{0 , 7 2 2}$ & 0,430 & 0,476 & 0,410 \\
EUS1 & 0,482 & 0,449 & 0,418 & $\mathbf{0 , 7 5 5}$ & 0,452 & 0,426 \\
EUS2 & 0,425 & 0,420 & 0,479 & $\mathbf{0 , 7 5 2}$ & 0,413 & 0,463 \\
EUS3 & 0,369 & 0,452 & 0,502 & $\mathbf{0 , 7 9 5}$ & 0,499 & 0,454 \\
FOR1 & 0,379 & 0,453 & 0,517 & 0,454 & $\mathbf{0 , 7 0 4}$ & 0,468 \\
FOR2 & 0,333 & 0,406 & 0,386 & 0,393 & $\mathbf{0 , 7 2 0}$ & 0,465 \\
FOR3 & 0,281 & 0,397 & 0,280 & 0,439 & $\mathbf{0 , 7 2 6}$ & 0,440 \\
FOR4 & 0,460 & 0,482 & 0,382 & 0,417 & $\mathbf{0 , 7 3 0}$ & 0,557 \\
TIM1 & 0,442 & 0,415 & 0,444 & 0,424 & 0,464 & $\mathbf{0 , 7 4 4}$ \\
TIM2 & 0,425 & 0,363 & 0,426 & 0,416 & 0,515 & $\mathbf{0 , 7 2 0}$ \\
TIM3 & 0,436 & 0,451 & 0,430 & 0,360 & 0,449 & $\mathbf{0 , 7 2 2}$ \\
TIM4 & 0,537 & 0,477 & 0,450 & 0,487 & 0,523 & $\mathbf{0 , 7 3 9}$ \\
\hline
\end{tabular}


Tabel 7. Luaran Perhitungan Kriteria Fornell-Lacker's

\begin{tabular}{ccccccc}
\hline & Accuracy & Content & $\begin{array}{c}\text { Ease of } \\
\text { Use }\end{array}$ & $\begin{array}{c}\text { End-User } \\
\text { Satisfaction }\end{array}$ & Format & Timeliness \\
\hline Accuracy & 0,728 & & & & & \\
Content & 0,547 & 0,762 & & & & \\
Ease of Use & 0,540 & 0,535 & 0,761 & & & \\
$\begin{array}{c}\text { End-User } \\
\text { Satisfaction }\end{array}$ & 0,553 & 0,574 & 0,608 & 0,768 & & \\
Format & 0,504 & 0,605 & 0,546 & 0,593 & 0,720 & \\
Timeliness & 0,634 & 0,584 & 0,599 & 0,583 & 0,670 & 0,731 \\
\hline
\end{tabular}

Tabel 7 memperlihatkan kuantitas akar AVE lebih besar dibandingkan dengan korelasi antar konstruknya, jadi diacu dari luaran perhitungan dua metode cross loading diperoleh bahwa discriminant validity sudah baik.

Ringkasan luaran pengolahan perhitungan Outer Loading disajikan Tabel 8, luaran tersebut memperlihatkan bahwa diagram riset telah menepati spesifikasi yang dapat diikhtisarkan diagram riset dapat diteruskan ke langkah perhitungan bentuk strukturnya (Hair et al., 2012; Afthanorhan, 2013). Kemudian, di langkah pengolahan bentuk strukturalnya dengan enam perhitungan yaitu: path coefficient $(\beta)$, coefficient of determination $\left(R^{2}\right)$, $t$-test menggunakan metode bootstrapping, effect size $\left(f^{2}\right)$, predictive relevance $\left(Q^{2}\right)$, dan relative impact $\left(q^{2}\right)$.

\section{a. Path Coefficient ( $\beta)$}

Perhitungan dijalankan sambil mencocokkan dengan besaran limitnya yang harusnya lebih besar dari 0,1 , relasi bisa dikatakan berdampak bila luaran perhitungan path coefficient lebih besar dari 0,1 . Luarannya dari 5 relasi di diagram riset, 4 relasi dikatakan mempunyai dampak penting dan 1 relasi tidak mempunyai dampak penting, yaitu: relasi Timeliness ke End-User Satisfaction. Pada Gambar 11 dan Tabel 9 ditunjukkan luaran perhitungan Path Coeffcient dan koefisien dengan alat bantu SmartPLS 3.2.7.

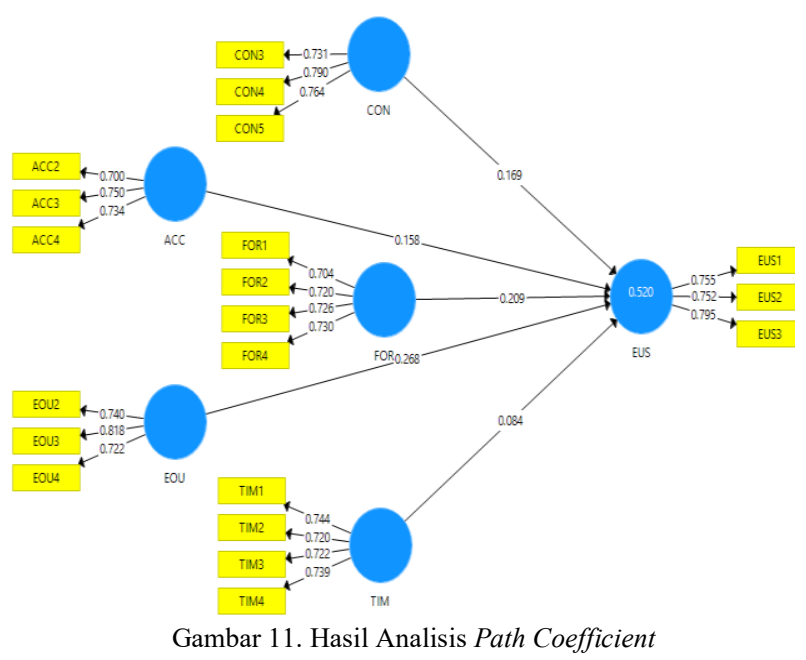

Tabel 8. Luaran Pengolahan Model Struktural

\begin{tabular}{|c|c|c|c|c|c|c|c|c|c|c|c|}
\hline \multirow{2}{*}{ Var } & \multirow{2}{*}{ Ind } & \multirow{2}{*}{ OL } & \multicolumn{6}{|c|}{ CL } & \multirow{2}{*}{ CR } & \multirow{2}{*}{ AVE } & \multirow{2}{*}{$\begin{array}{l}\text { Akar } \\
\text { AVE }\end{array}$} \\
\hline & & & $\mathrm{ACC}$ & CON & EOU & EUS & FOR & TIM & & & \\
\hline & $\mathrm{ACC}^{*}$ & & & & & & & & & & \\
\hline \multirow[t]{5}{*}{ ACC } & $\mathrm{ACC} 2$ & 0,700 & 0,700 & 0,341 & 0,386 & 0,394 & 0,372 & 0,467 & 0,722 & 0,530 & 0,728 \\
\hline & $\mathrm{ACC} 3$ & 0,750 & 0,750 & 0,419 & 0,397 & 0,399 & 0,340 & 0,427 & & & \\
\hline & $\mathrm{ACC} 4$ & 0,734 & 0,734 & 0,432 & 0,396 & 0,415 & 0,389 & 0,490 & & & \\
\hline & $\mathrm{CON}^{*}$ & & & & & & & & & & \\
\hline & $\mathrm{CON}_{2}$ & & & & & & & & & & \\
\hline \multirow[t]{4}{*}{$\mathrm{CON}$} & $\mathrm{CON} 3$ & 0,731 & 0,465 & 0,731 & 0,400 & 0,412 & 0,437 & 0,442 & 0,806 & 0,581 & 0,762 \\
\hline & $\mathrm{CON} 4$ & 0,790 & 0,385 & 0,790 & 0,336 & 0,447 & 0,441 & 0,410 & & & \\
\hline & CON5 & 0,764 & 0,404 & 0,764 & 0,486 & 0,452 & 0,503 & 0,484 & & & \\
\hline & EOU1* & & & & & & & & & & \\
\hline \multirow[t]{4}{*}{ EOU } & EOU2 & 0,740 & 0,403 & 0,448 & 0,740 & 0,431 & 0,365 & 0,427 & 0,805 & 0,579 & 0,761 \\
\hline & EOU3 & 0,818 & 0,474 & 0,423 & 0,818 & 0,520 & 0,411 & 0,522 & & & \\
\hline & EOU4 & 0,722 & 0,347 & 0,351 & 0,722 & 0,430 & 0,476 & 0,410 & & & \\
\hline & EUS1 & 0,755 & 0,482 & 0,449 & 0,418 & 0,755 & 0,452 & 0,426 & & & \\
\hline \multirow[t]{3}{*}{ EUS } & EUS2 & 0,752 & 0,425 & 0,420 & 0,479 & 0,752 & 0,413 & 0,463 & 0,811 & 0,589 & 0,768 \\
\hline & EUS3 & 0,795 & 0,369 & 0,452 & 0,502 & 0,795 & 0,499 & 0,454 & & & \\
\hline & FOR1 & 0,704 & 0,379 & 0,453 & 0,517 & 0,454 & 0,704 & 0,468 & & & \\
\hline \multirow[t]{5}{*}{ FOR } & FOR2 & 0,720 & 0,333 & 0,406 & 0,386 & 0,393 & 0,720 & 0,465 & 0,811 & 0,518 & 0,720 \\
\hline & FOR3 & 0,726 & 0,281 & 0,397 & 0,280 & 0,439 & 0,726 & 0,440 & & & \\
\hline & FOR4 & 0,730 & 0,460 & 0,482 & 0,382 & 0,417 & 0,730 & 0,557 & & & \\
\hline & TIM1 & 0,744 & 0,442 & 0,415 & 0,444 & 0,424 & 0,464 & 0,744 & & & \\
\hline & TIM2 & 0,720 & 0,425 & 0,363 & 0,426 & 0,416 & 0,515 & 0,720 & & & \\
\hline \multirow[t]{2}{*}{ TIM } & TIM3 & 0,722 & 0,436 & 0,451 & 0,430 & 0,360 & 0,449 & 0,722 & 0,821 & 0,535 & 0,731 \\
\hline & TIM4 & 0,739 & 0,537 & 0,477 & 0,450 & 0,487 & 0,523 & 0,739 & & & \\
\hline
\end{tabular}

Tabel 9. Luaran Perhitungan Path Coefficient dengan Alat Bantu SmartPLS 3.2.7

\begin{tabular}{cccc}
\hline & \multicolumn{4}{c}{ Accuracy } & Content & $\begin{array}{c}\text { Ease of } \\
\text { Use }\end{array}$ & $\begin{array}{c}\text { End-User } \\
\text { Satisfaction }\end{array}$ & Format & Timeliness \\
\hline Accuracy & 0,158 & \\
Content & 0,169 & \\
Ease of Use & 0,268 & \\
End-User & & \\
Satisfaction & 0,209 & \\
Format & 0.084 \\
Timeliness & & \\
\hline
\end{tabular}

\section{b. Coefficient of Determination $\left(R^{2}\right)$}

Sasaran perhitungan ini adalah sebagai keragaman tiap kriteria dengan acuan perhitungan sebesar 0,670 disebut kuat, sebesar 0,333 disebut moderat, dan 0,190 atau lebih kecil disebut lemah. Tabel 10 ditunjukkan End-User Satisfaction memiliki nilai $R^{2}$ yang moderat, dengan nilai yaitu 0,520 .

\section{Tabel 10. Luaran Perhitungan Coefficient of Determination $\left(R^{2}\right)$

\begin{tabular}{cc}
\hline & $\boldsymbol{R}^{\mathbf{2}}$ \\
\hline End-user satisfaction & 0,520 \\
\hline
\end{tabular}

\section{c. $t$-test}

Perhitungan t-test dioperasikan melalui alat bantu teknik bootstrapping dalam SmartPLS 3.0, dan kuantitas yang diperoleh lebih besar dari 1,96. Tabel 11 menunjukkan luaran perhitungan 5 relasi keseluruhan, 4 di antaranya yaitu: relasi Accuracy ke End-User Satisfaction, Content ke End-User Satisfaction, Ease of Use ke End-User Satisfaction, dan Format ke End-User Satisfaction memenuhi persyaratan. Sedangkan, satu relasi tidak disetujui, yaitu: Timeliness menuju End-User Satisfaction sebesar 1,191 . 
Tabel 11. Luaran Perhitungan t-test

\begin{tabular}{cc}
\hline & $\begin{array}{c}\text { T Statistics } \\
(|\mathbf{O} / \mathbf{S T D E V}|)\end{array}$ \\
\hline accuracy $\rightarrow$ end-user satisfaction & 3,125 \\
content $\rightarrow$ end-user satisfaction & 2,526 \\
Ease of use $\rightarrow$ end-user & 3,873 \\
satisfaction & 2,744 \\
Format $\rightarrow$ end-user satisfaction & 1,191 \\
Timeliness $\rightarrow$ end-user satisfaction &
\end{tabular}

\section{d. Effect Size $\left(f^{2}\right)$}

Langkah berikutnya adalah perhitungan $f^{2}$ yang dilaksanakan sebagai prakiraan dampak kriteria spesifik. Besarannya berkisar 0,02 yang disebut dampak kecil; sedangkan 0,15 sedang dan 0,35 berdampak besar. Tabel 12 menunjukkan luaran pengolahan, 5 lintasan/relasi mempunyai dampak kecil adalah Accuracy ke End-User Satisfaction skor 0,027; Content ke End-User Satisfaction skor 0,031; Ease of Use ke End-User Satisfaction skor 0,083; Format ke End-User Satisfaction skor 0,043 dan Timeliness menuju End-User Satisfaction dengan nilai 0,006 .

Tabel 12. Luaran Perhitungan Effect Size $\left(f^{2}\right)$

\begin{tabular}{|c|c|c|c|c|c|}
\hline \multicolumn{2}{|r|}{ Hipotesis } & \multicolumn{3}{|c|}{$f^{2}$} & \multirow{2}{*}{$\frac{\text { Analisis }}{f^{2}}$} \\
\hline No & Relasi & $R^{2}$-in & $R^{2}$-ex & $\sum \boldsymbol{f}^{2}$ & \\
\hline 1 & $\mathrm{CON} \rightarrow \mathrm{EUS}$ & 0,52 & 0,505 & 0,03125 & Kecil \\
\hline 2 & $\mathrm{ACC} \rightarrow \mathrm{EUS}$ & 0,52 & 0,507 & 0,02708 & Kecil \\
\hline 3 & $\mathrm{FOR} \rightarrow$ EUS & 0,52 & 0,500 & 0,04167 & Kecil \\
\hline 4 & EOU $\rightarrow$ EUS & 0,52 & 0,481 & 0,08125 & Kecil \\
\hline 5 & TIM $\rightarrow$ EUS & 0,52 & 0,517 & 0,00625 & Kecil \\
\hline
\end{tabular}

\section{e. Predictive Relevance $\left(Q^{2}\right)$}

$Q^{2}$ adalah nilai pengukuran sebuah model yang diuji pada relevansi prediktif antar konstruknya. Semakin tinggi nilai $Q^{2}$, maka semakin tinggi nilai relevansinya. Sesuai persyaratan, maka nilai $Q^{2}$ harus lebih besar daripada 0 (Urbach \& Ahlemann, 2010). Dari luaran perhitungan, didapatkan bahwa skor $Q^{2}$ dari semua kriteria lebih dari nol yang memperlihatkan hubungan validitas prediktif relevansi model adalah bersifat moderat. Nilai luaran ditunjukkan di Tabel 13.

\begin{tabular}{cc} 
Tabel 13. Luaran Perhitungan Predictive Relevance & $\boldsymbol{Q}^{\mathbf{2}}$ \\
\hline & 0,275 \\
\hline End-user satisfaction & 0,27 \\
\hline
\end{tabular}

\section{f. Relative Impact $\left(q^{2}\right)$}

Sama halnya dengan perhitungan $Q^{2}$, perhitungan berikutnya diterapkan melalui teknik blindfolding. Perhitungan ini berfungsi sebagai dampak relatif sebuah relevansi prediktif sebuah kriteria dengan kriteria lainnya. Bila besaran $f^{2}$ sekitar 0,02 disebut berdampak kecil; 0,15 berdampak sedang; dan 0,35 berdampak besar. Tabel 14 menunjukkan bahwa seluruh relasi mempunyai dampak kecil.

Tabel 14. Luaran Perhitungan Relative Impact $\left(q^{2}\right)$

\begin{tabular}{cccccc}
\hline \multicolumn{2}{c}{ Hipotesis } & \multicolumn{2}{c}{$\boldsymbol{q}^{\mathbf{2}}$} & Analisis \\
\hline No & Relasi & $\boldsymbol{Q}^{\mathbf{2}}$-in & $\boldsymbol{Q}^{\mathbf{2}}$-ex & $\sum \boldsymbol{q}^{\mathbf{2}}$ & $\boldsymbol{q}^{\mathbf{2}}$ \\
\hline 1 & CON $\rightarrow$ EUS & 0,275 & 0,268 & 0,010 & Kecil \\
2 & ACC $\rightarrow$ EUS & 0,275 & 0,269 & 0,008 & Kecil \\
3 & FOR $\rightarrow$ EUS & 0,275 & 0,266 & 0,012 & Kecil \\
4 & EOU $\rightarrow$ EUS & 0,275 & 0,257 & 0,025 & Kecil \\
5 & TIM $\rightarrow$ EUS & 0,275 & 0,278 & 0,004 & Kecil \\
\hline
\end{tabular}

Ikhtisar luaran perhitungan Inner Model dengan alat bantu SmartPLS 3.2.7 ditunjukkan di Gambar 12 .

\section{KESIMPULAN}

Berdasarkan Hipotesis yang diajukan dari 5 jalur variabel tersebut, dapat disimpulkan $\mathrm{H}_{0}$ ditolak untuk 4 kriteria yaitu Content, Accuracy, Format dan Easy of Use. Sedangkan $\mathrm{H}_{0}$ diterima untuk kriteria Timeliness. Mengacu pada luaran pengolahan data yang telah diperoleh, responden pada studi ini sebagian besar merasa puas sebesar $46 \%$, sedangkan $29 \%$ merasa cukup puas dan sisasnya sebesar $19 \%$ sangat puas Ketika menjalankan AUTO2000 Mobile. Terdapat 4 indikator dari 24 yang dihilangkan yaitu: ACC1, CON1, CON2 dan EOU1 dalam penelitian ini. Hal ini disebabkan masih adanya kriteria yang memiliki skor outer loading lebih kecil dari 0,7.

Satu dari lima jalur yaitu Timeliness menuju End-User Satisfaction dinyatakan memiliki pengaruh tidak signifikan, kemudian tidak diterima mengacu pada perhitungan t-test yang mempunyai dampak kecil pada perhitungan struktur model spesifik pada $f^{2}$ dan $q^{2}$. Empat dari lima jalur yaitu Content $(\mathrm{CON})$ menuju End-User Satisfaction (EUS), Accuracy (ACC) menuju End-User Satisfaction (EUS), Format (FOR) menuju End-User Satisfaction (EUS), dan Ease of Use (EOU) terhadap End-User Satisfaction (EUS) disebutkan mempunyai dampak penting terhadap empat relasi, lalu diterima mengacu pada

Gambar 12. Ringkasan Hasil Analisis Model Struktural

\begin{tabular}{|c|c|c|c|c|c|c|c|c|c|c|c|c|c|c|c|c|c|}
\hline \multicolumn{2}{|r|}{ Hipotesis } & \multirow{2}{*}{$\beta$} & \multirow{2}{*}{$t$-test } & \multirow{2}{*}{$R^{2}$} & \multicolumn{3}{|c|}{$f^{2}$} & \multirow{2}{*}{$Q^{2}$} & \multicolumn{3}{|c|}{$q^{2}$} & \multicolumn{6}{|c|}{ Analisis } \\
\hline No & Jalur & & & & $R^{2}$-in & $R^{2}$-ex & $\sum f^{2}$ & & $Q^{2}$-in & $Q^{2}$-ex & $\sum q^{2}$ & $\beta$ & t-test & $R^{2}$ & $f^{2}$ & $Q^{2}$ & $q^{2}$ \\
\hline 1 & $\mathrm{CON} \rightarrow \mathrm{EUS}$ & 0,169 & 2,526 & 0,52 & 0,52 & 0,505 & 0,03125 & 0,275 & 0,275 & 0,268 & 0,010 & Sign & Accepted & Moderate & Small & \begin{tabular}{|l|} 
Predictive \\
Relevance \\
\end{tabular} & Small \\
\hline 3 & FOR $\rightarrow$ EUS & 0,209 & 2,744 & 0,52 & 0,52 & 0,500 & 0,04167 & 0,275 & 0,275 & 0,266 & 0,012 & Sign & Accepted & Moderate & Small & \begin{tabular}{|l|} 
Predictive \\
Relevance \\
\end{tabular} & Small \\
\hline 4 & $\mathrm{EOU} \rightarrow \mathrm{EUS}$ & 0,268 & 3,873 & 0,52 & 0,52 & 0,481 & 0,08125 & 0,275 & 0,275 & 0,257 & 0,025 & Sign & Accepted & Moderate & Small & \begin{tabular}{|l|} 
Predictive \\
Relevance
\end{tabular} & Small \\
\hline
\end{tabular}


perhitungan t-test dan berdampak kecil pada perhitungan struktur model khususnya $f^{2}$ dan $q^{2}$.

Adapun keterbatasan penelitian ini adalah jumlah responden yang relatif kecil dibandingkan populasinya; konstruk dalam model masih melibatkan 5 variabel dasar EUCS di mana belum menyertakan variabel Security sebagai variabel yang perlu dipertimbangkan di era serba online, mengingat data pelanggan bersifat pribadi, dan harus terproteksi dengan benar. Keterbatasan teknis disebabkan oleh rentang waktu yang relative lama 2-3 bulan karena penyebaran kuesioner mencakup 2 tahap yaitu: Pre Test dan Real Questionnaire.

Sedangkan penelitian mendatang, peneliti mempertimbangkan variabel Timeliness sebagai investigasi lanjut karena variabel tersebut tidak berpengaruh secara langsung terhadap kepuasaan pengguna AUTO2000 Mobile; penambahan variabel Security dan Experience sebagai pengembangan model EUCS berikutnya; analisis kepuasan pengguna menggunakan data kualitatif dan mixed method; serta penggunaan metode secara paralel untuk mengukur kepuasan pelanggan seperti: Customer Satisfaction Surveys, Customer Satisfaction Score (CSAT), Net Promoter Score (NPS), atau Customer Effort Score (CES).

\section{UCAPAN TERIMA KASIH}

Peneliti mengucapkan terima kasih dan penghargaan kepada Prodi Sistem Informasi Fakultas Sains dan Teknologi UIN Syarif Hidayatullah Jakarta dan Departemen Communication \& Digital Marketing AUTO2000 PT. Astra International Tbk atas dukungannya sehingga terselenggaranya penelitian ini.

\section{DAFTAR PUSTAKA}

AFTHANORHAN, W., 2013. A comparison of partial least square structural equation modeling (PLS-SEM) and covariance based structural equation modeling (CB-SEM) for confirmatory factor analysis. International Journal of Engineering Science and Innovative Technology, 2(5), pp. 198-205.

AGGELIDIS, V.P., dan CHATZOGLOU, P.D., 2012. Hospital Information Systems: Measuring End User Computing Satisfaction (EUCS). Journal of Biomedical Informatics, 45(3), pp. 566-579.

CHIN, W. W., 1998. The partial least squares approach to structural equation modeling. Dalam: G. A. Marcoulides, ed. Modern Methods for Business Research. Mahwah, NJ: Lawrence Erlbaum Associates, pp. I295-1336.
DARWI, A. R. dan EFRIZON, E., 2019. Analisis Kepuasan Pengguna E-Learning Sebagai Pendukung Aktivitas Pembelajaran Menggunakan Metode EUCS. VOTEKNIKA, 7(1), pp. 25-31.

DOLL, W. J. dan TORKZADEH, G., 1988. The Measurement of End-User Computing Satisfaction. MIS quarterly, 12(2), pp. 259274.

FITRIANSYAH, A. dan HARRIS, I., 2018. Pengukuran Kepuasan Pengguna Situs Web dengan Metode End User Computing SaTisfaction (EUCS). QUERY: Jurnal Sistem Informasi, 2(1), pp. 1-8.

HAIR, J.F., SARSTEDT, M., RINGLE, R.M., dan MENA, J.A., 2012. An Assessment Of The Use of Partial Least Squares Structural Equation Modeling in Marketing Research. Journal of the academy of marketing science, Springer, 40(3), pp. 414-433.

HIDAYAH, N. A. dan RUSTAMAJI, E., 2018. Determining User Satisfaction Factors on University Tuition Fee Systems Using EndUser Computing Satisfaction (EUCS). 2018 6th International Conference on Cyber and IT Service Management (CITSM), IEEE, pp. $1-5$.

HUSAIN, T., 2018. Analisis End-User Computing Satisfaction (EUCS) dan WebQual 4.0 terhadap Kepuasan Pengguna. JATISI, 4(2), pp. 164-176.

JATI, H., WARDANI, R., HASANAH, N., BAITI, A. A., dan DESTIANA, B., 2015. Analisis Penerapan Sistem Informasi Akademik (SIAKAD) Menggunakan Model End-User Computing Satisfaction (EUCS) di Program Studi Pendidikan Teknik Informatika. Jurnal Electronics, Informatics, and Vocational Education (ELINVO), 1(1), pp. 53-64.

MARLINDAWATI, M., 2014. Analisis Tingkat Kepuasan Pengguna Perpustakaan Digital Universitas Bina Darma Palembang. In: Seminar Nasional Sains dan Teknologi Informasi 2014 - Senasti, 12 Mei 2014, Makasar.

MCLEOD JR, R. dan SCHELL, G.P., 2008. Sistem Informasi Manajemen Edisi 10. Jakarta: Salemba Empat.

PRATAMA, J.G., 2012. Analisa Sistem Informasi Entri KRS Online pada Universitas Bina Darma dengan Menggunakan Metode EUCS. B.A. Thesis. Universitas Bina Darma.

RASMAN, Y.I.K., 2012. Gambaran Hubungan Unsur-Unsur End-User Computing Satisfaction terhadap Kepuasan Pengguna Sistem Informasi Rumah Sakit di Rumah 
Sakit Umum Daerah Kota Depok. B.A. Thesis. Universitas Indonesia.

RESTANTI, A.S. dan ASTUTI, E.Y., 2017. Analisis End-User Computing Satisfaction pada Online Public Access Catalogue "Izylib" di Lingkungan Universitas Jenderal Soedirman. PUSTABIBLIA: Journal of Library and Information Science, 1(1), pp. 223-238.

SETIAWAN, A.B., 2016. Evaluasi Kepuasan Pengguna Sistem Aplikasi Surat Keterangan Tinggal Sementara Online (SKTS) dengan Menggunakan Metode End-User Computing Satisfaction. B.A. Thesis. Universitas Airlangga.

URBACH, N. dan AHLEMANN, F., 2010. Structural Equation Modeling in Information Systems Research Using Partial Least Squares. Journal of Information Technology Theory and Application (JITTA), 11(2), pp. 5-40.
YAMIN, S. dan KURNIAWAN, H., 2011. Generasi Baru Mengolah Data dengan Partial Least Square Path Modeling. Jakarta: Salemba Infotek.

YAZID, M.A., WIJOYO, S.H., dan ROKHMAWATI, R. I., 2019. Evaluasi Kualitas Aplikasi Ruangguru Terhadap Kepuasan Pengguna Menggunakan Metode EUCS (End-User Computing Satisfaction) dan IPA (Importance Performance Analysis). Jurnal Teknologi Informasi dan Ilmu Komputer (JTIIK), 3(9), pp. 84968505. 